ISSN 2227-7099

www.mdpi.com/journal/economies

Article

\title{
Union Bargaining in an Oligopoly Market with Cournot-Bertrand Competition: Welfare and Policy Implications
}

\author{
Elizabeth Schroeder and Victor J. Tremblay * \\ Department of Economics, Oregon State University, Corvallis, OR, 97331-3612, USA; \\ E-Mail: liz.schroeder@oregonstate.edu \\ * Author to whom correspondence should be addressed; E-Mail: victor.tremblay@ oregonstate.edu; \\ Tel.: +1-541-737-1471; Fax: +1-541-737-5917.
}

Received: 6 January 2014; in revised form: 11 February 2014 / Accepted: 10 March 2014 /

Published: 25 March 2014

\begin{abstract}
We investigate the welfare effect of union activity in a relatively new oligopoly model, the Cournot-Bertrand model, where one firm competes in output ( la Cournot) and the other firm competes in price ( la Bertrand). The Nash equilibrium prices, outputs, and profits are quite diverse in this model, with the competitive advantage going to the Cournot-type competitor. A comparison of the results from the Cournot-Bertrand model with those found in the traditional Cournot and Bertrand models reveals that firms and the union have a different preference ordering over labor market bargaining. These differences help explain why the empirical evidence does not support any one model of union bargaining. We also examine the welfare and policy implications of union activity in a Cournot-Bertrand setting.
\end{abstract}

Keywords: Cournot-Bertrand model; union bargaining

JEL classifications: C72, D43, L13

\section{Introduction}

Union membership in the United States has steadily declined since its peak in the 1950s. A growing number of states have adopted laws that restrict union power, and recent years have seen intense debates over policies such as right-to-work laws, which allow employees at unionized firms to opt out 
of paying union dues. In order for policymakers to weigh the costs of inefficiencies that can be created by unions against concerns for equity and redistribution, it is important to understand the differential impact of union power in various market structures.

In this paper, we investigate the effect of union activity in duopoly markets and the conditions under which union power has the greatest impact on allocative efficiency. We consider both Cournot and Bertrand models, but our main emphasis is on a relatively new model, the Cournot-Bertrand model. In this case, one firm competes in output (as in Cournot) and the other firm competes in price (as in Bertrand) within the same industry. The main reason for considering this model is that it produces an outcome where firms are heterogeneous, a common feature in the real world. In addition, Tremblay, et al. [1] observe that real markets exist in which some firms compete in output and others compete in price. The market for automobiles provides an excellent example. This is a market where workers are unionized and Scion behaves as a Bertrand competitor, while Honda behaves as a Cournot competitor. At Scion customers order a style of automobile and accessories from a menu. Price is set and non-negotiable. Alternatively, Honda establishes a fixed inventory each month and allows the price to adjust to meet its monthly sales goal. To our knowledge, we are the first to study firm-union bargaining in a Cournot-Bertrand framework. ${ }^{1}$

We consider the three principle bargaining rules, or models of union behavior: the monopoly union (MU), the right-to-manage (RTM), and the efficient bargaining (EB) models. The MU model assumes that firms and unions compete in a two stage game. In the first stage, the union chooses the wage rate that maximizes its objective function, which is generally defined to be a function of wages and employment. In the second stage, each firm observes the union wage and maximizes profit with respect to employment. In the subgame-perfect Nash equilibrium to this game, the union correctly anticipates the firm's best reply to its wage offer, which is the firm's labor demand, and then chooses the optimal wage. The firm then maximizes profit, subject to the wage that is set by the union.

The RTM model is similar to the MU model, except that the firm and union collectively bargain over the wage rate in the first stage. This is an attractive feature of the model, as the wage is normally determined through collective bargaining between firms and unions. This model allows us to introduce a parameter that captures the relative bargaining power of firms $v s$. the union, and to show how this parameter influences wages, employment, and output relative to the socially efficient quantity. In fact, the MU model is a special case of the RTM model in which unions have all of the bargaining power in the first stage. The main weakness of both the MU and RTW models, however, is that they each produce a Pareto inefficient outcome - there are alternative wage-employment pairs that make both the union and the firms better off.

In response, the EB model of union behavior was developed. In this case, the firm and union simultaneously bargain over employment and the wage in order to maximize the joint returns of the union and firms. This produces a Pareto efficient wage-employment outcome. The traditional criticism of this model is that the structure of the game is not consistent with reality: firms and unions generally bargain over wages and not employment. A more fundamental problem that has not been discussed in

${ }^{1}$ For example, Petrakis and Vlassis [2] investigate these issues in a Cournot model with homogeneous goods. For a review of the literature and empirical evidence regarding firm-union bargaining, see Goeddeke [3] and Lawson [4]. The Cournot-Bertrand model is discussed in Singh and Vives [5], Martin [6], Tremblay and Tremblay [7], and Tremblay, et al. [8]. 
the literature is that when the elasticity of substitution between labor and other inputs is low, an EB agreement forces firms to compete in a Cournot type game. With the extreme Leontief (fixed-proportion) technology, for example, setting the level of employment effectively sets the level of output. With output determined, firms cannot compete in price as Bertrand competitors.

This raises the fundamental question: why should firms compete in output or in price? Both types of actions are observed in the real world. Kreps and Scheinkman [9] provide a viable explanation. Although they use a two-stage model, Tirole [10] points out that the Kreps and Scheinkman model "reflects the idea that when prices adjust more quickly than capacities" or inventories, the Cournot outcome is reached. This would apply to heavy manufacturing industries where planning and production times are lengthy. Such industries may also be more likely to use a relatively fixed-proportion technology, at least in the short run. For example, Kemfert [11] found that the elasticity of substitution between labor and capital in motor vehicles production is low (at 0.1) compared to food preparation (at 0.66). Alternatively, when prices are sticky and production is flexible, firms will tend to compete in price. Fast-food restaurants and software companies are good examples where these conditions hold and firms compete in price. $^{2}$

Since Cournot competition allows any of the three types of bargaining, a Cournot-type firm may prefer efficient bargaining, which maximizes joint returns. On the other hand, a Bertrand-type firm facing Leontief technology would not be able to take advantage of efficient bargaining without incurring a cost. Such a firm would have to switch to Cournot-type behavior, which could be too expensive. Thus, Bertrand-type firms may prefer to deal with a monopoly union or within a right-to-manage framework.

This may explain why the empirical evidence does not provide unanimous support for any one model of union bargaining. Many empirical studies pool data from a variety of industries, but industries vary considerably in their technologies, demand conditions, and the strategies chosen by firms. In addition, each union model has different strengths and weaknesses. For example, the transaction cost of bargaining would be considerably higher with efficient bargaining compared to a monopoly union framework. Thus, the optimal type of firm-union bargaining is likely to differ by industry. It is also likely to vary across states and countries with different regulations and attitudes about union activity.

These arguments motivate our work on firm-union behavior. We begin by analyzing the familiar MU, RTM, and EB models in a Cournot duopoly market and the MU and RTM models in a Bertrand duopoly market. Then we analyze firm-union bargaining in a Cournot-Bertrand market. We investigate the welfare and policy implications of each of these models. We show that the results are sensitive to the structure of labor and output markets, and that policies that decrease union bargaining power will have more of an effect on allocative efficiency under certain market structures.

\footnotetext{
${ }^{2}$ As a referee points out, however, in practice it can be difficult to determine if a firm is setting price or quantity.
} 


\section{The Model}

Consider a market with two firms (1 and 2) that bargain over a wage contract with a single (industry wide) union. Product differentiation exists and is driven by consumer taste for variety (Beath and Katsoulacos, [12]). A model with this type of product differentiation can be described by an inverse demand system that is similar to that of Bowley [13], Dixit [14] and Singh and Vives [5]: ${ }^{3}$

$$
\begin{aligned}
& p_{1}\left(q_{1}, q_{2}\right)=1-q_{1}-d q_{2} \\
& p_{2}\left(q_{1}, q_{2}\right)=1-q_{2}-d q_{1}
\end{aligned}
$$

where $p_{i}$ is the price of good $i$ ( 1 or 2$), q_{i}$ is the quantity of good $i$, and $d \in[0,1]$ is an index of product differentiation. Products 1 and 2 are homogeneous when $d=1$, and each firm is a monopolist when $d=0$. Thus, differentiation increases as $d \rightarrow 0$.

Firms have no monopsony power and face the same Leontief technology. Capital and other inputs are assumed to be in sufficient supply so that firm $i$ 's production function is $q_{i}=\alpha L_{i}$, where $L_{i}$ is the quantity of labor employed by firm $i$ and $\alpha$ represents the productivity of labor. Let parameter $\alpha$ equal 1 for convenience. Notice that with this technology, firm-union bargaining that sets $L_{i}$ also sets $q_{i}$, forcing firms to be Cournot competitors in the output market. Under these conditions, firm $i$ 's profit function is $\pi_{i}=p_{i} q_{i}-w q_{i}$, where $w$ is the price of labor and the marginal (average) cost of production.

The objective of unions remains largely unknown (Lawson, [4]). We assume that the union's goal is to maximize the economic rent of union members: $\mathrm{U}=\left(w-w_{\mathrm{o}}\right) Q$, where $Q=q_{1}+q_{2}$ (or $L_{1}+L_{2}$ ), $w \in[0,1)$, and $w_{\mathrm{o}}$ is the competitive wage or the opportunity cost of labor. If the union has no bargaining power, then the equilibrium wage will equal $w_{\mathrm{o}}$. For simplicity, $w_{\mathrm{o}}$ is set to $0 .{ }^{4}$

We use this framework to investigate the MU, RTM, and EB models when firms compete in a duopoly output market. We begin by considering the traditional Cournot and Bertrand models. These models are well known and provide results that are used to compare with those of the Cournot-Bertrand model. For the remainder of this section, we assume that each firm's choice of strategic variable (output or price) and the type of firm-union bargaining rule (MU, RTM, or EB) are exogenously given. The effect of endogenizing these choices will be discussed in Section 3. In the formal models below, players are assumed to have complete and perfect information.

\subsection{Cournot Competition}

In the first two firm-union bargaining models, players compete in a two-stage game. The wage is determined in the first stage (I), using either a MU or RTM bargaining rule. In the second stage (II), firms simultaneously compete in output. In the EB model, the wage and firm levels of employment (and output) are chosen in the first stage of negotiation, effectively eliminating Stage II.

\footnotetext{
${ }^{3}$ That is, this demand system derives from the representative consumer's utility function $\mathrm{U}\left(q_{1}, q_{2}\right)=\left(q_{1}+q_{2}\right)-\left(q_{1}^{2}+q_{2}^{2}+\right.$ $\left.2 d q_{1} q_{2}\right) / 2+m$, where $m$ is the quantity of all other goods and has a price that is normalized to 1 .

${ }^{4}$ Alternatively, from the union's perspective one can think of $w$ as the markup of the union wage over the competitive wage.
} 
We first consider the MU model. We calculate the subgame-perfect Nash equilibrium (SPNE) to this game using backwards induction. In Stage II of the game, firms simultaneously choose output. The Nash equilibrium (NE) in this stage game is: ${ }^{5}$

$$
q_{i}^{*}=\frac{1-w}{2+d} ; p_{i}^{*}=\frac{1+w(1-d)}{2+d} ; \pi_{i}^{*}=\frac{(1-w)^{2}}{(2+d)^{2}}
$$

Because $L_{i}=q_{i}, q_{i}^{*}$ is firm $i$ 's best-reply function and its labor demand. In Stage I, the union correctly anticipates each firm's best reply in the later stage, and maximizes $\mathrm{U}\left(w, q_{1}^{*}, q_{2}^{*}\right)$ with respect to $w$. The SPNE to this game is:

$$
\begin{gathered}
w^{C-M U}=\frac{1}{2} ; U^{C-M U}=\frac{1}{2(2+d)} ; \\
q_{i}^{C-M U}=\frac{1}{2(2+d)} ; p_{i}^{C-M U}=\frac{3+d}{2(2+d)} ; \pi_{i}^{C-M U}=\frac{1}{4(2+d)^{2}}
\end{gathered}
$$

In terms of notation, superscript $C-M U$ identifies SPNE values in the MU model when firms compete as Cournot competitors in Stage II. As expected, an increase in product differentiation (i.e., a decrease in $d$ ) benefits both the union and firms. This is true for all subsequent models.

Next, we consider the RTM model where the union and firms collectively bargain over the wage rate in Stage I. The NE in Stage II is the same as in (3). In Stage I, the union and firms correctly anticipate the best-replies in Stage II and use this information to bargain over $w$. To allow for different degrees of bargaining power, let players maximize the following asymmetric Nash bargaining equation $(N B):^{6}$

$$
N B=U^{a}\left(\pi_{1}+\pi_{2}\right)^{(1-a)}
$$

Parameter $a \in[0,1]$ represents the union's relative bargaining power. ${ }^{7}$ When $a=1$, the union has all the power; when $a=0$, all of the bargaining power goes to the firms. The Stage I game is solved by maximizing (5) with respect to $w$, given the best-reply functions in Equation (3). The SPNE to this game is:

$$
\begin{gathered}
w^{C-R T M}=\frac{a}{2} ; U^{C-R T M}=\frac{a(2-a)}{2(2+d)} ; \\
q_{i}^{C-R T M}=\frac{2-a}{2(2+d)} ; p_{i}^{C-R T M}=\frac{2+a+a d}{2(2+d)} ; \pi_{i}^{C-R T M}=\frac{(2-a)^{2}}{4(2+d)^{2}}
\end{gathered}
$$

Superscript $C-R T M$ identifies SPNE values in the RTM model when firms compete as Cournot competitors in Stage II. In this model, firm profits increase and union welfare decreases as union power diminishes (i.e., as $a$ decreases). When $a=0$, firm profits are maximized and union rents are zero. Notice that the model reverts to MU when $a=1$. Thus, the MU model is a special case of the RTM model.

\footnotetext{
${ }^{5}$ The comparative static results are as expected. Greater product differentiation (i.e., a decrease in $d$ ) leads to higher prices and profits. An increase in wages leads to higher prices and lower profits.

${ }^{6}$ For a discussion of this bargaining approach, see Roth [15], McDonald and Solow [16], and Binmore, et al. [17].

${ }^{7}$ For example, Binmore, et al. [17] show that a player's bargaining power diminishes as the player becomes more impatient during the bargaining process or believes that there is a higher probability that negotiations will break down.
} 
Finally, we consider the EB model, where all negotiations take place in Stage I. That is, players maximize Equation (5) with respect to $w, L_{1}=q_{1}$, and $L_{2}=q_{2}$. The fixed-proportion technology forces firms to compete in output (Cournot) in Stage I and eliminates Stage II of the game. The NE to this game is:

$$
\begin{gathered}
w^{C-E B}=\frac{a}{2} ; U^{C-E B}=\frac{a}{2(1+d)} \\
q_{i}^{C-E B}=\frac{1}{2(1+d)} ; p_{i}^{C-E B}=\frac{1}{2} ; \pi_{i}^{C-E B}=\frac{1-a}{4(1+d)}
\end{gathered}
$$

Superscript $C-E B$ identifies NE values in the EB model. As with the RTM model, union welfare increases and firm profits decrease with increases in union bargaining power (i.e., as $a$ increases).

\subsection{Bertrand Competition}

In this section, we assume the same game structure as above, except that firms compete in price instead of output in Stage II. This eliminates the possibility of efficient bargaining, however, because such bargaining would dictate output levels and make Bertrand (price) competition impossible. As a result, only the MU and RTM models are relevant in the Bertrand framework.

In the Bertrand model, the inverse demand Equations (1) and (2) must be transformed so that the choice variables are on the right-hand side of each equation. This produces the following demand function for firm $i$ :

$$
q_{i}\left(p_{i}, p_{j}\right)=\frac{(1-d)-p_{i}+d p_{j}}{1-d^{2}}
$$

where subscript $i$ identifies Firm 1 or 2 and subscript $j$ identifies the other firm. In each model, we calculate the SPNE, using backwards induction. In Stage II of the game, firms simultaneously choose price. The NE in this stage game is: ${ }^{8}$

$$
p_{i}^{*}=\frac{1-d+w}{2-d} ; q_{i}^{*}=\frac{1-w}{2+d-d^{2}} ; \pi_{i}^{*}=\frac{(1-w)(1-d)^{2}}{(1+d)(2-d)^{2}}
$$

In Stage I, the wage rate is determined. With the MU model, the union correctly anticipates the firms' NE behavior in the future period and maximizes $\mathrm{U}\left(w, q_{1}^{*}, q_{2}^{*}\right)$ with respect to $w$. The SPNE to this game is:

$$
\begin{gathered}
w^{B-M U}=\frac{1}{2} ; U^{B-M U}=\frac{1}{2\left(2+d-d^{2}\right)} ; \\
q_{i}^{B-M U}=\frac{1}{2\left(2+d-d^{2}\right)} ; p_{i}^{B-M U}=\frac{3-2 d}{2(2-d)} ; \pi_{i}^{B-M U}=\frac{1-d}{4(1+d)(2-d)^{2}}
\end{gathered}
$$

Superscript $B-M U$ identifies SPNE values in the MU model when there is Bertrand behavior in the output market. The model illustrates the Bertrand paradox: as $d \rightarrow 1$, price approaches marginal cost $(w)$ and profits approach zero.

In the RTM model, the union and firms collectively bargain over the wage rate in Stage I. The NE in Stage II is unchanged, and the Nash bargaining equation is the same as Equation (5). In Stage I, the

\footnotetext{
${ }^{8}$ The comparative static results are as expected. Greater product differentiation (i.e., a decrease in $d$ ) leads to higher prices and profits. An increase in wages leads to higher prices and lower profits.
} 
SPNE is solved by maximizing (5) with respect to $w$, given the optimal behavior in Stage II. The SPNE is:

$$
\begin{gathered}
w^{B-R T M}=\frac{a}{2} ; U^{B-R T M}=\frac{a(2-a)}{2\left(2+d-d^{2}\right)} \\
q_{i}^{B-R T M}=\frac{2-a}{2\left(2+d-d^{2}\right)} ; p_{i}^{B-R T M}=\frac{2+a-2 d}{2(2+d)} ; \pi_{i}^{B-R T M}=\frac{(1-d)(2-a)^{2}}{4(1+d)(2-d)^{2}}
\end{gathered}
$$

As in the Cournot model, the Bertrand-RTM outcome is the same as that of the MU model when $a=1$. In addition, union welfare increases and firm profits decrease with union bargaining power (i.e., as $a$ increases).

\subsection{Cournot-Bertrand Competition}

The model of interest that has not been investigated in the union context is the Cournot-Bertrand model. Here, Firm 1 competes in output, as in Cournot, while Firm 2 competes in price, as in Bertrand. The other characteristics of the game are the same as in the Cournot and Bertrand cases. Because one firm competes in price, efficient bargaining is not possible with the Cournot-Bertrand model. ${ }^{9}$

Operationally, the inverse demand Equations (1) and (2) are transformed so that the choice variables are on the right-hand side of each equation. This produces the following demand system:

$$
\begin{gathered}
p_{1}\left(q_{1}, p_{2}\right)=(1-d)-\left(1-d^{2}\right) q_{1}+d p_{2} \\
q_{2}\left(q_{1}, p_{2}\right)=1-p_{2}-d q_{1}
\end{gathered}
$$

In each model, the SPNE is calculated using backwards induction. In Stage II of the game, Firm 1 chooses output and Firm 2 chooses price, decisions that are made simultaneously. The NE of this stage game is: ${ }^{10}$

$$
\begin{gathered}
p_{1}^{*}=\frac{\left(2-d-2 d^{2}+d^{3}\right)+w\left(2+d-d^{2}-d^{3}\right)}{4-3 d^{2}} \leq p_{2}^{*}=\frac{\left(2-d-d^{2}\right)+w\left(2+d-d^{2}\right)}{4-3 d^{2}} ; \\
q_{1}^{*}=\frac{(1-w)(2-d)}{4-3 d^{2}} \geq q_{2}^{*}=\frac{(1-w)\left(2-d-d^{2}\right)}{4-3 d^{2}} ; \\
\pi_{1}^{*}=\frac{(1-w)^{2}(2-d)^{2}\left(1-d^{2}\right)}{\left(4-3 d^{2}\right)^{2}} \geq \pi_{2}^{*}=\frac{(1-w)^{2}\left(2-d-d^{2}\right)^{2}}{\left(4-3 d^{2}\right)^{2}}
\end{gathered}
$$

Consistent with the analysis of the Cournot-Bertrand model without a union (Tremblay and Tremblay [16] and Tremblay, et al. [8]), our model generates an asymmetric equilibrium where the Cournot-type firm has the strategic advantage (as long as $d>0$ ). Given the high degree of heterogeneity in firm behavior, bargaining costs may be substantially higher in the Cournot-Bertrand model, an issue we take up in the next section.

\footnotetext{
${ }^{9}$ Another possibility is that the union uses a different bargaining strategy with each firm. This would allow for efficient bargaining with the Cournot-type firm and MU or RTM bargaining with the Bertrand-type firm. This would impose high transaction costs on the union, however.

${ }^{10}$ The comparative static results are as expected. Greater product differentiation (i.e., a decrease in $d$ ) leads to higher prices and profits. An increase in wages leads to higher prices and lower profits.
} 
In Stage I, the players correctly anticipate future NE behavior. With the MU model, the union maximizes $\mathrm{U}\left(w, q_{1}^{*}, q_{2}^{*}\right)$ with respect to $w$. The SPNE to this game is:

$$
\begin{gathered}
w^{C B-M U}=\frac{1}{2} ; U^{C B-M U}=\frac{4-2 d-d^{2}}{4\left(4-3 d^{2}\right)} ; \\
q_{1}^{C B-M U}=\frac{2-d}{2\left(4-3 d^{2}\right)} \geq q_{2}^{C B-M U}=\frac{(2-a)\left(2-d-d^{2}\right)}{2\left(4-3 d^{2}\right)} ; \\
p_{1}^{C B-M U}=\frac{6-d-5 d^{2}+d^{3}}{2\left(4-3 d^{2}\right)} \leq p_{2}^{C B-M U}=\frac{6-d-4 d^{2}}{2\left(4-3 d^{2}\right)} \\
\pi_{1}^{C B-M U}=\frac{(2-d)^{2}\left(1-d^{2}\right)}{4\left(4-3 d^{2}\right)^{2}} \geq \pi_{2}^{C B-M U}=\frac{\left(2-d-d^{2}\right)^{2}}{4\left(4-3 d^{2}\right)^{2}}
\end{gathered}
$$

Superscript $C B-M U$ identifies SPNE values in the MU model when firms compete as Cournot-Bertrand competitors in Stage II. As with the previous cases, the MU model is a special case of the RTM model, which we discuss next.

In the RTM model, there is collective bargaining over the wage rate in Stage I, based on the Nash bargaining Equation (5) and the anticipated best replies in Stage II. The SPNE is:

$$
\begin{gathered}
w^{C B-R T M}=\frac{a}{2} ; U^{C B-R T M}=\frac{(2-a) a\left(4-2 d-d^{2}\right)}{4\left(4-3 d^{2}\right)} ; \\
q_{1}^{C B-R T M}=\frac{(2-a)(2-d)}{2\left(4-3 d^{2}\right)} \geq q_{2}^{C B-R T M}=\frac{(2-a)\left(2-d-d^{2}\right)}{2\left(4-3 d^{2}\right)} ; \\
p_{1}^{C B-R T M}=\frac{2\left(2-d-2 d^{2}+d^{3}\right)+a\left(2+d-d^{2}-d^{3}\right)}{2\left(4-3 d^{2}\right)} \leq p_{2}^{C B-R T M} \\
=\frac{2\left(2-d-d^{2}\right)+a\left(2+d-2 d^{2}\right)}{2\left(4-3 d^{2}\right)} ; \\
\pi_{1}^{C B-R T M}=\frac{(2-a)^{2}(2-d)^{2}\left(1-d^{2}\right)}{4\left(4-3 d^{2}\right)^{2}} \geq \pi_{2}^{C B-R T M}=\frac{(2-a)^{2}\left(2-d-d^{2}\right)^{2}}{4\left(4-3 d^{2}\right)^{2}}
\end{gathered}
$$

Because this is the first application of the Cournot-Bertrand model in the presence of a union, we discuss the results in some detail. First, the degree of product differentiation has a dramatic effect on the outcome. When $d=0$, each firm is a simple monopolist, as in the Cournot and Bertrand models. Unlike previous models, however, firms are asymmetric in equilibrium when $d$ exceeds 0 . The Cournot-type firm has the strategic advantage and produces more output than the Bertrand-type firm when $0<d<1$. The most striking result occurs when $d=1$. In this case, the equilibrium price equals marginal cost $(w)$, and Firm 1 produces all that is demanded at that price. Firm 2 is effectively eliminated from the market, and both firms earn zero profit. Thus, the market outcome is the same as perfect competition even though production is monopolized by a single firm. ${ }^{11}$

Second, union bargaining power affects equilibrium values. As in the Cournot and Bertrand models, union welfare increases and firm profits decrease with union bargaining power (i.e., as $a$ increases). When $a=1$, the union has all of the bargaining power and the RTM model reverts to the MU model. When $a=0$, firms have all of the bargaining power and union welfare is zero. Unlike previous models, however, union bargaining power has an asymmetric effect on firm profits. An increase in union

\footnotetext{
${ }^{11}$ Tremblay and Tremblay [7] identified this result in the Cournot-Bertrand model without a union.
} 
power causes greater harm to Firm 1, the more profitable firm, than Firm 2. ${ }^{12}$ This implies that the union is better able to extract rents from more profitable firms.

\section{Welfare, Endogenous Choices, and Bargaining Rules}

In this section, we discuss the effects of different union bargaining rules (MU, RTM, and EB) and different output models (Cournot, Bertrand, and Cournot-Bertrand) on firm, union, and social welfare. Our results help explain why more than a single bargaining rule may be used in the real world. We also consider the conditions under which union power has a greater or lesser effect on allocative efficiency.

Two comparative static results hold in all of the models discussed above. First, both firms and the union benefit from product differentiation. Product differentiation increases the market power of firms, creating greater exploitable profit opportunities for all players. Second, an increase in the bargaining power of the union (an increase in $a$ ), benefits the union at the expense of the firms. Union welfare is maximized when the union has all of the bargaining power $(a=1)$. Firm welfare is maximized when firms have all of the bargaining power $(a=0)$.

Regarding the output market, consider the case where there is no union and firms have the choice of competing in output or price. In models with the demand and cost structures described above, the dominant strategy is to compete in output (Singh and Vives [14]; Tremblay, et al. [8]). This result holds when a union is added. In the RTM model, for example, average firm profits are highest in the Cournot model and lowest in the Bertrand model. ${ }^{13}$ To illustrate, when $a=0.25$ and $d=0.5, \pi_{i}^{C-R T M}=$ $0.1225>\pi_{1}^{C B-R T M}=0.1223>\pi_{2}^{C B-R T M}=0.1133>\pi_{i}^{B-R T M}=0.1134 .{ }^{14}$ Firms that compete in the Bertrand game and the Bertrand-type firm (Firm 2) in the Cournot-Bertrand game earn the lowest profit.

Nevertheless, there are several reasons why it may be more profitable for one or both firms to compete in price instead of output. As discussed in the introduction, the Kreps and Scheinkman [9] model reflects the idea that firms will prefer price competition when prices are inflexible relative to production. In addition, Tremblay, et al. [8] show that the mix of Cournot-Bertrand behavior can be supported when there are suitable demand or cost asymmetries to induce just one firm to behave as a Bertrand competitor. In furniture manufacturing, for example, capacity may adjust relatively slowly for mass-producers, causing them to behave as Cournot competitors. In contrast, custom furniture manufactures establish a price menu and behave as Bertrand competitors. Union activity would not affect a firm's decision to behave as a Cournot or Bertrand competitor. Thus, one would expect to see union activity in Cournot, Bertrand, and Cournot-Bertrand type markets. Nonetheless, one would only see efficient bargaining in markets where firms compete in output or where there is little substitutability between labor and other inputs.

In the models discussed above, the union has a different preference ordering over bargaining rules than do the firms. In the RTM model, for example, firm welfare is always highest with Cournot behavior, while union welfare is always highest for Bertrand behavior and lowest for Cournot

\footnotetext{
${ }^{12}$ From the profit equations in (16), $\frac{\partial \pi_{i}^{C B-R T M}}{\partial a}<0$ and $\left|\frac{\partial \pi_{1}^{C B-R T M}}{\partial a}\right|>\left|\frac{\partial \pi_{2}^{C B-R T M}}{\partial a}\right|$.

${ }^{13}$ One can prove this by comparing the profit equations in (6), (11), and (16).

${ }^{14}$ In general, the relative performance of the profits obtained from efficient bargaining depends upon the specific values of $a$ and $d$. In this case, $\pi_{i}^{C-E B}=0.125$.
} 
behavior. In addition, the union is not always better off with efficient bargaining (assuming no additional transfers from firms). To illustrate, when $a=0.25$ and $d=0.5, U^{B-R T M}=0.0972>$ $U^{C B-R T M}=0.0925>U^{C-R T M}=0.0875>U^{C-E B}=0.0833 .{ }^{15}$

These firm and union welfare results help explain why the empirical evidence does not clearly support any one model of union bargaining. Clearly, players benefit collectively from using efficient bargaining, but this requires Cournot behavior when technology is close to being fixed-proportion. Thus, we may not observe efficient bargaining in all unionized markets, especially where there is Bertrand competition. First, Bertrand-type firms will prefer MU or RTM over EB if the cost of switching from Bertrand to Cournot behavior is sufficiently high. In addition, our model demonstrates that there are cases where unions prefer Bertrand-type markets.

Another factor that would affect union activity is the degree of heterogeneity within a given industry, as in the Cournot-Bertrand model. With imperfect and incomplete information, greater heterogeneity between firms within an industry would raise the transaction cost of reaching a collective bargaining agreement. In an industry such as this, MU and RTM bargaining, which have only one bargaining instrument $(w)$, may be less costly than EB, which has three bargaining instruments $\left(w, L_{1}\right.$, and $\left.L_{2}\right)$. In this case, MU or RTM bargaining may be preferred over EB by firms and the union.

The final welfare issue involves the effect of union activity on allocative efficiency. Two conditions guarantee allocative efficiency in output and input markets. First, the union has no bargaining power. Second, firms have no market power (as buyers of labor services or sellers of output). In the input market, this causes $\mathrm{w}$ to equal the competitive wage, which is 0 in our model. In the output market, this causes price to equal marginal cost. With the demand and cost functions used above, the market is allocatively efficient when industry production is $Q^{A E}=2 /\left(2+d-d^{2}\right)$. As expected, Bertrand competition is more socially efficient than Cournot-Bertrand and Cournot competition. ${ }^{16}$ In the RTM model, when $a=0.25$ and $d=0.5$, then $Q^{A E}=0.889>Q^{B-R T M}=0.778>Q^{C B-R T M}=0.740>$ $Q^{C-R T M}=0.700 .^{17}$

Industry production falls as union bargaining power increases, except in the efficient bargaining model, where industry output is unaffected by union power. Thus, the presence of a union cannot improve efficiency in this model. ${ }^{18}$ The degree of inefficiency generated by union power differs, however, depending on market structure. Consider the total quantity, $Q$, produced by each type of duopoly under RTM bargaining. In each case, increasing union power, $a$, decreases $Q$, moving it farther away from the allocatively efficient quantity, $Q^{A E}$. The derivatives are a function of $d$, given by the following expressions:

$$
\frac{\partial Q^{C-R T M}}{\partial a}=\frac{-1}{2+d} ; \frac{\partial Q^{C-R T M}}{\partial a}=\frac{-1}{2+d} ; \frac{\partial Q^{C B-R T M}}{\partial a}=\frac{-4+2 d+d^{2}}{8-6 d^{2}}
$$

\footnotetext{
${ }^{15}$ In general, the relative performance of the profits obtained from efficient bargaining depends upon the specific values of $a$ and $d$. As expected, total union and industry returns are highest for the EB model for all acceptable values of $a$ and $d$.

${ }^{16}$ This can be proven by inspecting the output equations in (6), (11), and (16).

${ }^{17}$ The relative performance of the efficient bargaining model depends upon the specific values of $a$ and $d$.

${ }^{18}$ Of course, unions can promote efficiency when facing a monopsonist or oligopsonists.
} 
These derivatives are plotted on Figure 1. They are all negative, demonstrating than an increase in union power reduces efficiency. When $d=0$ (each firm is a monopolist), the derivative of $Q$ with respect to $a$ is -0.5 . As $d$ increases (i.e., the degree of product differentiation decreases), $\partial Q / \partial a$ is closest to zero in the Cournot case, with the gap widening as $d$ grows. A value closer to zero, or smaller in absolute value, indicates that increasing union power has less of an impact on output. Thus, the inefficiency generated by union power is smallest in a Cournot duopoly. The reduction in output is largest in a Bertrand market, and the Cournot-Bertrand duopoly produces intermediate results.

Figure 1. The impact of union power on output, according to market structure and product differentiation.

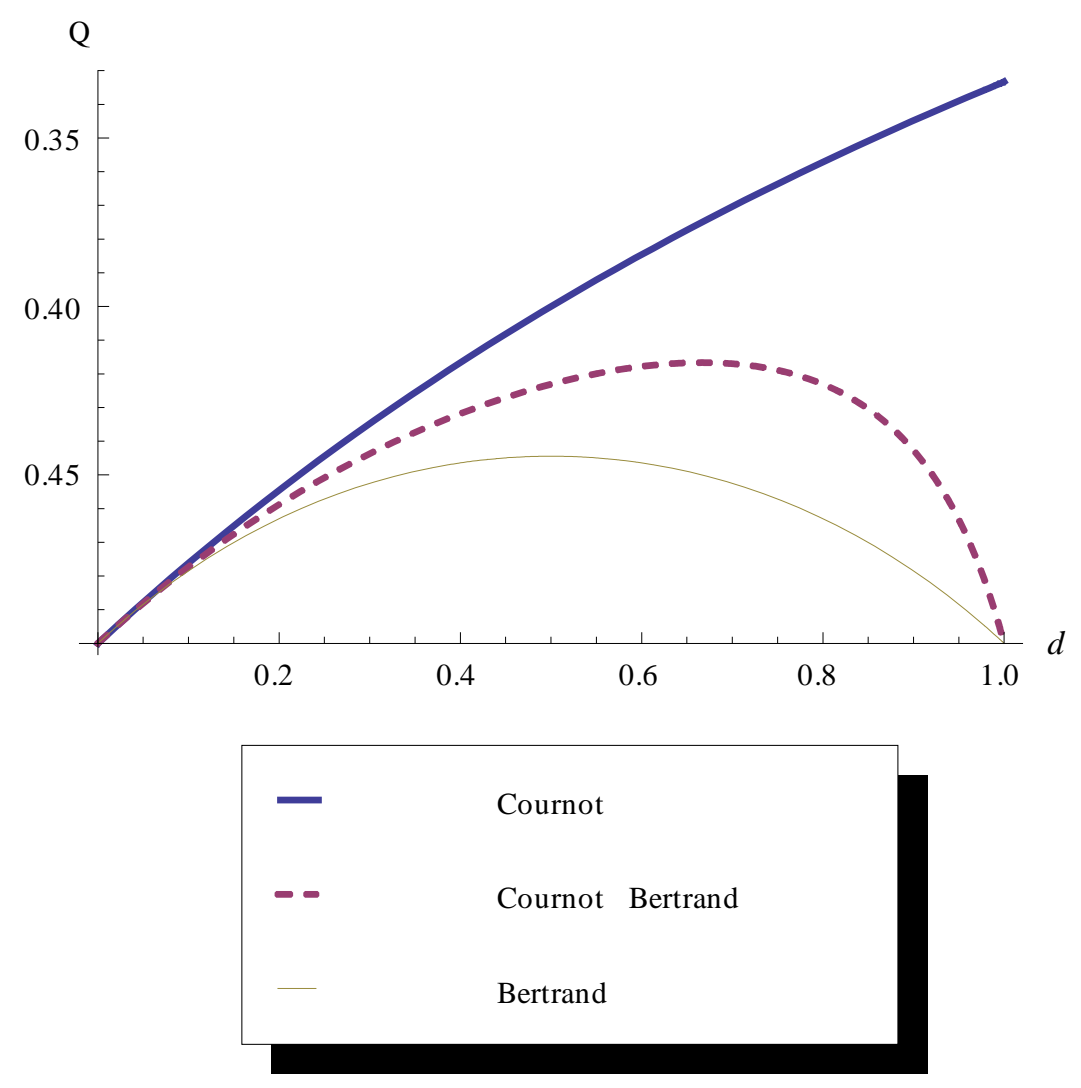

\section{Conclusions and Policy Implications}

In this paper, we analyze market outcomes in oligopoly markets when firms face an industry wide union. Three popular models of union behavior are considered: the monopoly union, right-to-manage, and efficient bargaining models. We investigate three output market models: the Cournot, Bertrand, and Cournot-Bertrand models. This is the first paper to investigate the effect of union activity in a Cournot-Bertrand setting.

Three main results emerge from this study. First, efficient bargaining produces the best outcome for firms and the union combined, suggesting that one should only observe efficient bargaining in the real world. Yet, the empirical evidence does not clearly support the efficient bargaining model over other models. Previous studies and our analysis help explain this result. In an industry with a relatively fixed-proportion technology, efficient bargaining forces firms to compete in output (as in Cournot). 
From the firm's perspective, however, there are market conditions under which Bertrand or Cournot-Bertrand competition is preferred to Cournot competition (Kreps and Scheinkman, [9]; Tremblay, et al. [8]). If the cost of switching from price to output competition is sufficiently high, these firms will reject Cournot competition and efficient bargaining. From the union's perspective, our model demonstrates that there are conditions under which unions do not prefer efficient bargaining (assuming no transfers). Thus, not all unions will prefer Cournot competition and efficient bargaining. Given transaction costs and the amount of firm heterogeneity that exists across industries in the real world, one would expect to observe a variety of bargaining rules.

Finally, even though firms bargain with a single union and face the same demand and cost conditions, the equilibrium outcome is asymmetric in the Cournot-Bertrand model. The Cournot-type firm produces greater output and earns greater profits than the Bertrand-type firm. This is in contrast to the Cournot and Bertrand models where firms are symmetric in equilibrium. Because the cost of reaching a firm-union agreement may be higher with efficient bargaining and in markets with more heterogeneous firms, firms and unions alike may prefer a monopoly union or a right-to-manage bargaining rule over efficient bargaining in markets with greater diversity.

From a policy perspective, the main channel through which lawmakers can adjust the equityefficiency balance of union activity is by changing the relative strength of union bargaining power. Policymakers may wish to increase union power to address inequality. For example, because the evidence shows that market power contributes to income or wealth disparities, the government may wish to promote unions as a way of re-distributing these gains from the wealthy to the poor (see Tremblay and Tremblay [18] for a discussion). On the other hand, increasing union power moves equilibrium output farther away from the allocatively efficient quantity (assuming no monopsony power), in addition to decreasing firm profits.

There are a variety of policies that lawmakers use to influence union bargaining power. As mentioned above, right-to-work laws that allow employees to choose not to join a union or pay union dues, even when they benefit from union negotiations, have been enacted in several states, and were the subject of a heated controversy recently in Michigan. These laws can be interpreted as weakening union bargaining power. Binmore, et al. [17] show that a player's bargaining power diminishes as the player becomes more impatient during the bargaining process or believes that there is a higher probability that negotiations will break down. Policies that make unions more patient, such as more generous unemployment benefits, would therefore increase union power. In addition, union bargaining power would be increased by policies that give unions more faith in the negotiating process, such as a more favorable mediation process or, more generally, a legal system that is not viewed as giving an advantage to large corporations.

If policymakers wish to promote unions for equity reasons, they may prefer to do so in markets in which union power has less of an effect on output. In our models, union power is the least distortionary in Cournot markets, in that a change in union power has the smallest effect on industry output in the Cournot model. Unions decrease output by the greatest amount in Bertrand markets. Thus, industries that typically compete as Cournot, such as heavy manufacturing, are more efficient places from society's perspective to increase union power. In Bertrand-type industries, such as software and telecommunications, the efficiency loss from increasing union power to address equity issues will be greatest. Industries that compete as Cournot-Bertrand have an intermediate impact on allocative 
efficiency, but approach the Bertrand result when the degree of product differentiation is extremely low and extremely high. Our work makes it clear that it will be more difficult to identify an optimal policy in Cournot-Bertrand type markets because firms are so diverse, and because the social effect of union power varies so greatly with the degree of product differentiation.

\section{Acknowledgements}

We would like to thank Carol Tremblay and two anonymous referees for their helpful comments on an earlier version of the paper.

\section{Conflicts of Interest}

The authors declare no conflict of interest.

\section{References}

1. Tremblay, V.J.; Tremblay, C.H.; Isariyawongse, K. Cournot and Bertrand Competition when advertising rotates demand: The case of Honda and Scion. Int. J. Econ. Bus. 2013, 20, 125-141.

2. Petrakis, E.; Vlassis, M. Endogenous scope of bargaining in a union-oligopoly model: When will firms and unions bargain over employment? Labor Econ. 2000, 7, 261-281.

3. Goeddeke, A.K. Unionized Oligopolies-A Survey. Available online: http://dx.doi.org/ 10.2139/ssrn.1617649 (accessed on 29 May 2010).

4. Lawson, N.P. Is collective bargaining Pareto efficient? A survey of the literature. J. Labor Res. 2011, 32, 282-304.

5. Singh, N.; Vives, X. Price and quantity competition in a differentiated duopoly. Rand J. Econ. 1984, 15, 546-554.

6. Martin, S. Advanced Industrial Organization; Blackwell Publishers: Oxford, UK, 2002; p. 82.

7. Tremblay, C.H.; Tremblay, V.J. The Cournot-Bertrand model and the degree of product differentiation. Econ. Lett. 2011, 111, 233-235.

8. Tremblay, V.J.; Tremblay, C.H.; Isariyawongse, K. Endogenous timing and strategic choice: The Cournot-Bertrand model. Bull. Econ. Res. 2013, 65, 332-342.

9. Kreps, D.; Scheinkman, J. Quantity precommitment and Bertrand competition yield Cournot outcomes. Bell J. Econ. 1983, 14, 326-337.

10. Tirole, J. The Theory of Industrial Organization; MIT Press: Cambridge, MA, USA, 1988; p. 233.

11. Kemfert, C. Estimated substitution elasticities of a nested CES production function approach for Germany. Energy Econ. 1998, 20, 249-264.

12. Beath, J.; Katsoulacos, Y. The Economic Theory of Product Differentiation; Cambridge University Press: Cambridge, UK, 1991.

13. Bowley, A.L. The Mathematical Groundwork of Economics; Oxford University Press: Oxford, USA, 1924.

14. Dixit, A. A model of duopoly suggesting a theory of entry. Bell J. Econ. 1979, 10, 20-32.

15. Roth, A. Axiomatic Models of Bargaining; Springer-Verlag: Berlin, Germany, 1979.

16. McDonald, I.M.; Solow, R.M. Wage bargaining and employment. Am. Econ. Rev. 1981, 71, 896-908. 
17. Binmore, K.; Rubinstein, A.; Wolinsky, A. The Nash bargaining solution in economic modeling. Rand J. Econ. 1986, 17, 176-188.

18. Tremblay, V.J.; Tremblay, C.H. New Perspectives on Industrial Organization: With Contributions from Behavioral Economics and Game Theory; Springer: New York, NY, USA, 2012.

(C) 2014 by the authors; licensee MDPI, Basel, Switzerland. This article is an open access article distributed under the terms and conditions of the Creative Commons Attribution license (http://creativecommons.org/licenses/by/3.0/). 